\title{
Teaching Russian abroad: the concept of additional professional training
}

\author{
Elena Mikhailovna Markova ${ }^{1}$, Alina Aleksandrovna Pozdnyakova ${ }^{1 *}$, and Elena \\ Romualdovna Laskareva ${ }^{2}$ \\ ${ }^{1}$ The Kosygin State University of Russia, Institute of International Education, Moscow, Russia \\ ${ }^{2}$ St. Petersburg State University, Faculty of Philology, St. Petersburg, Russia
}

\begin{abstract}
The importance of a qualitative renewal of the additional professional training system for Russian language teachers of foreign schools gives rise to many problems of both theoretical and organizational nature. The following ones are particularly relevant: 1) the determination of professional deficits of teaching staff; 2) the identification of gaps in the current system of additional professional training for Russian as a foreign language teachers; 3) the correction of the identified professional deficiencies through additional educational programs on various directions and degrees of complexity. The solution to these problems is impossible in the absence of the concept of additional professional training system for Russian as foreign language teachers, formed on the basis of an ethnooriented approach, which involves the development of models of advanced training for teaching specific ethnic groups. Such a concept can be implemented through a system of diagnostic and educational events held remotely in a controlled segment of the Internet (on the platform of a specific educational institution or its autonomous substructure). Since the organization of additional professional training for Russian as foreign language teachers of foreign schools is closely related to the type of educational institution in which the teacher works (national state, national non-state, weekend school, schools under the Russian Orthodox Church, etc.), it is advisable to consider the educational content of advanced training programs from two points of view: 1) from the point of view of the requirements for the training of the contingent of students, 2) from the point of view of the requirements for the personality of the teacher of a particular educational institution. Taking these factors into account is important, since it directly affects the nature of the training content and the technologies used. This study offers the options for modular educational programs for additional training in three fields of activity (subject, organizational, methodological, psychological): 1) the program "Difficult cases of Russian grammar and Russian word usage", aimed at eliminating gaps in the field of subject competences; 2) the program "Problems of teaching the Russian language in a limited language environment", aimed at eliminating gaps in the organizational and methodological sphere; 3 ) the program "Psychological foundations of organizing educational activities in a foreign language", aimed at eliminating gaps in the field of psychological competencies. Sequential remote implementation of modules included in
\end{abstract}

* Corresponding author: apozdnyakova@live.ru 
additional professional training programs will provide access to up-to-date methodological knowledge for a large number of teachers of Russian as a foreign language.

Keywords: educational process, distance learning, distance educational technologies, electronic learning environment (ELE), Russian as a foreign language (RFL).

\section{Introduction}

Additional professional training for Russian language teachers of foreign schools is a priority task of the RF policy in the field of education. This is due to a number of factors.

First, the Russian language today is under the influence of global processes, which creates the need for additional support for its purity and originality. The tendency towards the universalization of knowledge, understood as "a consequence and result of complicated interethnic and interethnic ties" [1], creates the preconditions for the loss of the national component of the vocabulary, the erosion of the cultural layer of the language, which has a detrimental effect on its existence and functioning as a single organism. The activities of Russian schools abroad can significantly affect the deactivation of these processes. Studying the Russian language raises the awareness of foreigners about Russian culture, helps fight stereotypes and promotes the "Russian brand". In addition, in modern conditions, additional responsibility is imposed on foreign schools in connection with the importance of the state conducting competent, careful foreign policy activities.

Secondly, the growing interest of foreign citizens in life in Russia stimulates the need for a new generation of specialists. Today, Russian as a foreign language (RFL) teachers should be highly educated, capable of giving students a high-quality language education, as well as well-trained technically, possessing a set of competencies in the field of distance, information and telecommunication technologies. The systematic improvement of the professional skills of teachers, bringing them in line with the "requirements of the time" also meets the objectives of promoting the Russian language and education in Russian.

Finally, the "human factor" of the state educational policy should be born in mind. The constantly changing reality forces the teachers of Russian schools abroad to be in constant readiness for various kinds of "transformations", which significantly increases the psychological load on the teacher's personality. Supporting a teacher as a "translator", a popularizer of Russian culture, preparing him for manifestations of psychological discomfort is extremely important and should be reflected in the system of additional professional training. Without correcting the internal and external conditions of educational activity, it is impossible for a teacher to carry out a full-fledged educational process.

All this speaks of the importance of a qualitative renewal of the system of additional professional training of teachers of the Russian language in foreign schools, bringing it in line with the goals and objectives of training personnel in the higher education system.

Additional professional training of the RFL teachers will be most effective if a number of conditions are met, the main of which are:

1. Creation of the concept of a system of additional professional training of a teacher of Russian as a foreign language on the basis of an ethno-oriented approach, which involves the development of models of advanced training for teaching specific ethnic groups.

2. Formation of the teacher's professional competencies in the field of distance technologies, focused on a specific subject area (teaching foreign languages); continuous improvement of the teacher in this area.

3. Creation of high-quality programs for additional professional training of the RFL teacher, containing relevant educational content, formed taking into account the lacunes 
(subject, methodological, psychological) identified through diagnostic testing of teachers; their subsequent implementation using the latest remote, information and telecommunication technologies.

These ideas of work are being implemented within the framework of the Concept "Russian School Abroad", approved on November 4, 2015, which implies active state support for Russian schools at all levels - information, material and technical, methodological, organizational, including in the system of additional professional education [2].

\section{Methods}

To achieve the goal and solve the set tasks, the following methods are used in the work: theoretical analysis of linguistic, psychological, pedagogical, sociological literature related to the problem under study; analysis of the existing programs for professional development of foreign languages teachers (including Russian as a foreign language); studying the practice of organizing courses for distance support of learning foreign languages (Russian and foreign); questionnaires, testing, surveys of users of current courses; analysis of expert opinions and procedures for assessing the quality of online learning; analysis of generalized statistical data concerning the experience of organizing online Russian language teaching [3-5]. "Open resources providing continuous professional education for RFL teachers" [67], which include "massive open online courses, online lectures, scientific and methodological webinars, online lessons, scientific and practical conferences" [8-10] served as the material for the analysis.

When creating training modules, the authors relied on the Russian traditions of teaching Russian as a foreign language and used the general approaches adopted in the theory and practice of teaching languages: communicative, sociocultural, problematic, competencebased. From foreign sources, the works of the Australian linguist David Noonan, devoted to teaching English as a second language and organizing online courses, turned out to be useful [11-13].

To form the general structure of the modular course, an integrative-network approach was used, which makes it possible to connect the elements of the modules by introducing the plug-ins into modern software systems and / or on distance learning platforms, to organize a feedback process between participants in the educational process [7, 14-17].

\section{Results}

Based on the analysis of test results and identification of deficiencies in professional competencies, the authors have developed three programs of additional professional training with a total labor intensity of 72 academic hours each and proposed a training model for the developed programs using distance technologies on the platform https://edu.rguk.ru of The Kosygin State University of Russia. The implementation of the programs allows:

1) to increase the level of professional competencies of teachers of foreign schools by mastering the developed programs of additional professional education;

2) to provide access to up-to-date methodological knowledge to a large number of teachers of Russian as a foreign language through the online format of the proposed advanced training course;

3) to familiarize teachers with the possibilities of using Russian educational Internet resources in the field of teaching Russian as a foreign language. 
We also add that the additional training programs developed within the framework of this study, as well as educational and methodological materials, services for the RFL teachers and foreign citizens will be able to find wide application in the system of Russian additional education.

\section{Discussion}

As part of the project, programs of additional education are offered in each of the three areas of the teacher's professional activity (subject, organizational and methodological, psychological).

\subsection{The program "Difficult cases of Russian grammar and Russian word usage"}

The program "Difficult cases of Russian grammar and Russian word usage" is aimed at eliminating gaps in the field of subject competencies and includes 7 modules.

Module 1 "Russian literary language as a normalized and processed form of the common language" examines the features of the formation of grammatical norms of the Russian language - historically developed and theoretically meaningful rules for the formation of word forms and the construction of syntactic structures. The module draws the listeners' attention to "unstable parts of the grammatical system", where the variability of linguistic units which are the difficult cases of the use of grammatical (morphological and syntactic) phenomena is manifested. The formation of a standardized Russian speech is defined as the main problem of teaching Russian as a foreign language and as a foreign language.

Module 2 "Difficult cases in the use of nouns" examines the norms for using the gender of nouns, as well as cases of deviations from the norms, special cases of the formation of case meanings and number values, the possibility of variable use of the singular and plural in texts of different style orientations.

Module 3 "Difficult cases in the use of adjectives" examines the rules for the use of adjectives, as well as violations associated with the formation of short forms of adjectives and forms of degrees of comparison; analyzes variants of synonymous replacement of an adjective with an indirect noun.

Module 4 "Difficult cases in the use of numerals" examines the rules of using the numerals, as well as the violations associated with the change in the case of numbers of different types (simple, complex, composite).

Module 5 "Difficult cases in the use of pronouns" examines the norms of use of pronouns, as well as the violations associated with the formation of pronouns and the change of pronouns of different types in cases (numbers, gender).

Module 6 "Difficult cases in the use of verbs and verb forms" examines the rules for the use of perfect and imperfect verbs, as well as the violations associated with the formation and use of special forms of the verb in writing - participles and participles. Particular attention is paid to the use of verbal derivatives (nouns, adjectives, adverbs) of prefixed and non-prefixed verbs.

Module 7 "Consistency in violation of certain syntactic norms of the Russian language by foreigners" examines the rules for the construction and use of phrases and sentences in Russian speech, as well as the violations of syntactic norms associated with the incorrect order of words and parts of sentences, with the use of homogeneous members and parts of the same type in simple and complex sentences. The module summarizes the most 
common mistakes made by foreign students in the study of the Russian language and describes the methods of their corrections.

The implementation of the program makes it possible to eliminate gaps in the subject area identified during diagnostic testing.

\subsection{The program "Problems of teaching the Russian language in a limited language environment"}

The program "Problems of teaching the Russian language in a limited language environment" is aimed at eliminating gaps in the organizational and methodological sphere and includes 7 modules.

Module 1 "The language environment as the most important factor in teaching foreign languages" examines the teaching components of the language environment, the methods of pedagogical management of the language environment, the features of the development of the linguistic personality in the linguistic environment, specifies the professional functions of the teacher during the period of organizing training in various conditions: linguistic environment, outside the linguistic environment. The module analyzes the teacher's activities to create a learning language environment that helps to improve the process of teaching Russian as a foreign language and has a positive effect on the development of the secondary linguistic personality (term by Khaleeva [18, p. 278]).

Module 2 "Requirements for mastering the Russian language and subjects in Russian in the context of situational bilingualism" examines the levels of proficiency in Russian as a foreign language, which determine the degree of formation of communicative competence in RFL, as well as the features of the development and implementation of programs that regulate the preparation of students outside the Russian language environment or in a limited language environment. The module also contains an analysis of the regulatory framework that defines the requirements for the level of training of foreign citizens entering Russian educational institutions.

Module 3 "Teaching Russian as a foreign language and subjects in Russian, taking into account the different orientation of educational programs" examines the specifics of Russian general education programs of higher and secondary education, as well as the specifics of teaching Russian as a foreign language to foreign citizens mastering these educational programs.

Module 4 "Teaching the Russian language and subjects in Russian, taking into account the ethnic and religious composition of the students" regulates the need to study ethnocultural, sociolinguistic, religious factors in the educational process in relation to the object of training; considers the religious-ethnic component as a "factor of influence" in the linguistic development of society, and taking into account the ethnic and religious composition of the students as an important requirement for education in a foreign language. The module analyzes the peculiarities of teaching the Russian language, as well as other subjects in Russian to various ethnic and religious categories of students, the formation of tolerant consciousness in learning conditions in mixed groups (see [19-23]).

Module 5 "Teaching the Russian language and subjects in Russian, taking into account the age characteristics of students" examines the peculiarities of teaching subjects of different cycles to students of different age groups. The module analyzes the forms, methods, techniques, preferred for teaching certain categories of foreign citizens (children, adolescents, adults and elderly people).

Module 6 "Test control in the system for assessing language competencies and initial subject knowledge" is concerned with the analysis of the forms, methods and techniques of testing common in the practice of Russian as a foreign language and as a nonnative language, Russian for bilinguals. The article considers a linguodidactic test - a set of 
tasks prepared in accordance with certain requirements, which makes it possible to identify the degree of development of language and speech competence in the tested; the features of the organization and conduct of certification testing in Russian as a foreign language, as well as the features of testing different groups of bilinguals (children and adults) are analyzed.

Module 7 "Multimedia cultural and linguistic environment as a factor in the successful mastery of the Russian language and Russian culture" is concerned with the analysis of existing electronic resources created by specialists from Russian and foreign universities and including educational materials (online textbooks and teaching aids, multimedia courses, etc.) for the development of skills speech activity of students of different categories. Particular attention is paid to informing the students of the additional training program about the possibilities of Russian educational Internet resources, their integration into the global educational space.

Mastering this program allows the RFL teachers to eliminate gaps in the methodological sphere, identified during diagnostic testing.

\subsection{The program "Psychological foundations of organizing educational activities in a foreign language"}

The program "Psychological foundations of organizing educational activities in a foreign language" is aimed at eliminating gaps in the field of psychological competencies. It includes 7 modules.

Module 1 "Speech activity as a subject of study in teaching a foreign language" describes the psychological mechanisms, types and levels of speech activity (motivationalincentive, orienting-research, executive, subject and operational); the speech is considered as a way of forming and formulating thoughts, the factors influencing the process of comprehension and memorization are defined.

Module 2 "Speech activity and psychological type of personality of a student" analyzes the relationship between speech and personality, highlighting various approaches to understanding the language personality. Speech activity is considered in the aspect of creating a flexible system of teaching Russian as a foreign language, satisfying different contingents and different abilities of learners [24]. The age and national characteristics of speech activity are analyzed, the importance of speech as an indicator and factor in the development of the student's personality is emphasized.

Module 3. "The relationship between learning and motivation in mastering a foreign language" examines the role of motives in learning Russian as a foreign language, their psychological structure, emphasizes the importance of active teaching methods (problematic, research, gaming) for the formation of cognitive motivation for learning a foreign language (Russian as foreign).

Module 4 "Personality-activity and audiolingual approaches to teaching Russian as a foreign language in a limited language environment" examines the psychological mechanisms of organizing personal-activity and audiolingual approaches to teaching foreign languages, issues of the effectiveness of using these approaches when teaching Russian as a foreign language; describes the means of immersing students in the language environment, substantiates the importance of the parallel application of both approaches in a limited language environment for the formation of such types of speech activities as listening, writing and reading.

Module 5 "Development of foreign language abilities as the basis for individualization of teaching a foreign language" examines the role of individual differences in the success of mastering a foreign language and RFL, defines the components of the psychological structure of foreign language abilities and features of their 
development in students of different age groups, analyzes the influence of individual psychological factors on the success of learning speech interaction in a foreign language.

Module 6 "Psychological analysis of the RFL lesson" examines the principles and methods of psychological analysis of a foreign language lesson and RFL, highlights the preliminary, current and retrospective types of lesson analysis, allows the listener to evaluate their own lessons according to the proposed scheme.

Module 7 "Professionally significant personal qualities of a foreign language teacher" examines methods of studying professionally significant personal characteristics of a teacher, assesses categories such as a predisposition to teaching activity and suitability for it, defines the psychological characteristics of the formation of the style of teaching activity of an RFL teacher.

Mastering this program allows the RFL teacher to eliminate the competence gaps in the psychological sphere, identified during diagnostic testing (see [25]).

The complexity of each program is 72 academic hours. The theoretical material of the courses is presented in the form of video lectures, developed in accordance with the problems of the designated educational modules. Mastering the lecture material is carried out through the participation of listeners in online seminars (webinars) and completing assignments for independent work. At the same time, the independent work of students is at least $30 \%$ of the total complexity of the program. The level of formation of professionally significant competencies is checked through a test control system. Monitoring of the learning outcomes is carried out through the "Test" resource of the ELE.

\section{Conclusion}

In conclusion, the authors would like to note that the features of the organization of additional professional training of the RFL teacher of a foreign school are determined by the nature of his activities, namely: being outside the Russian language environment, responsibility for the quality of training of a foreign student mastering Russian in a limited language environment, as well as the inclusion of additional professional training in the system of continuing professional education. These factors require consideration when updating the current system of continuing professional education.

\section{References}

1. A.A. Pozdnyakova, Language issues arising from globalization, Prepodavatel XXI vek, 2 (2), 277-283 (2011)

2. Kontseptsiya "Russkaya shkola za rubezhom” (utv. Prezidentom RF 04.11.2015 № Pr2305) [Concept "Russian School Abroad" (approved by the President of the Russian Federation on 04.11.2015 No. Pr-2305)]. Accessed on: July 28, 2021. [Online]. Available: http://kremlin.ru/acts/news/copy/50643

3. TALIS 2018 Results (Volume I): Teachers and School Leaders as Lifelong Learners, TALIS (OECD Publishing, Paris, 2019). https://doi.org/10.1787/1d0bc92a-en

4. TALIS 2018 Results (Volume II): Teachers and School Leaders as Valued Professionals, TALIS (OECD Publishing, Paris, 2020). https://doi.org/10.1787/19cf08df-en

5. Positive, High-achieving Students? What Schools and Teachers Can Do, TALIS (OECD Publishing, Paris, 2021). https://doi.org/10.1787/3b9551db-en)

6. V.N. Klimova, I.K. Nefedova, Sozdanie sistemy distantsionnoi professionalnoi podderzhki kak instrument obespecheniya nepreryvnogo obrazovaniya prepodavatelei 
RKI [Creation of a system of distance professional support as a tool for providing continuous education for RFL teachers], in V.N. Klimov (ed.), Collection of articles, International scientific and practical conference "Electronic resources of open education in the Russian language: best practices", December 7-8, 2017, Moscow, 6671 (Moscow, 2018)

7. N.V. Kulibina, N.B. Bitekhtina, N.V. Vinogradova, T.N. Diachenko, V.N. Klimova, A.I. Olkhovskaya, The World of Russian Word, 1, 85-89 (2018)

8. B.C. Tretyakov, V.A. Larionova, Higher Education in Russia, 7(203), 55-66 (2016)

9. E.G. Azimov, Russian Language Abroad, 4, 12-18 (2017)

10. N.V. Kulibina, Interaktivnyi urok kak forma uchebnogo vzaimodeistviya $\mathrm{v}$ elektronnom obrazovatelnom resurse [Interactive lesson as a form of educational interaction in an electronic educational resource], in I.A. Leshutin (ed.), Collection of articles, International Scientific and Practical Conference "Slavic Culture: Origins, Traditions, Interaction. XIX Cyril and Methodius Readings" in the framework of the International Cyril and Methodius Festival of Slavic Languages and Cultures, May 2325, 2018, 650-655 (Moscow, 2018)

11. D. Nunan, The Learner-Centred Curruculum (CUP, Cambridge, 1988)

12. D. Nunan, Syllabus Design (OUP, Oxford, 1991)

13. D. Nunan, Learner-Centered English Language Education (Routledge, New York, 2012)

14. P. Fidalgo, J. Thormann, O. Kulyk, J.A. Lencastre, Students' perceptions on distance education: A multinational study, Int J Educ Technol High Educ, 17, 18 (2020). https://doi.org/10.1186/s41239-020-00194-2

15. M. Cooch, Moodle 2.0 First Look (Packt Publishing, 2010)

16. Working Group on Education: Digital skills for life and work (September 2017). Broadband Commission for Sustainable Development. Accessed on: July 28, 2021. [Online]. Available: https://d-russia.ru/wp-content/uploads/2017/10/Digital-skills-forlife-and-work_259013e.pdf

17. I.A. Orekhova, Virtualnaya yazykovaya sreda, realnaya yazykovaya sreda $\mathrm{i}$ yazykovaya lichnost [Virtual linguistic environment, real linguistic environment and linguistic personality], in M.N. Rusetskaya (ed.), Collection of articles, Materials of the International Scientific and Practical Conference "Slavic Culture: Origins, Traditions, Interaction. XIX Cyril and Methodius Readings" in the framework of the International Cyril and Methodius Festival of Slavic Languages and Cultures, May 23-25, 2018, 521-524, (Moscow, 2019)

18. I.I. Khaleeva, Vtorichnaya yazykovaya lichnost kak retsipient inofonnogo teksta [Secondary linguistic personality as a recipient of a foreign text], in Yu.S. Stepanov, E.A. Zemskaya, A.M. Moldovan (eds.), Language - system. Language - text. Language - ability (RAS RFL, Moscow, 1995)

19. A. Pidgeon, N. Rowe, P. Stapleton, H. Magyar, B. Lo, Open Journal of Social Sciences, 2, 14-22 (2014). https://doi.org/10.4236/jss.2014.211003

20. D.R.E. Cotton, T. Nash, P. Kneale, European Educational Research Journal, 16(1), $62-$ 79 (2017). https://doi.org/10.1177/1474904116652629

21. T.M. Mandalaywala, D.M. Amodio, M. Rhodes, Social Psychological and Personality Science, 9(4), 461-469 (2018). https://doi.org/10.1177/1948550617707020

22. M. Bornschlegl, D. Cashman, Open Learning: The Journal of Open, Distance and eLearning, 34(2), 139-155 (2019). https://doi.org/10.1080/02680513.2018.1509695 
23. H. Mostafa, Y. Lim, Journal of International Students, 10(2), 306-319 (2020). https://doi.org/10.32674/jis.v10i2.603

24. M. Jacobs, T.S.C. Farrell, RELC Journal, 34(1), 5-30 (2003). https://doi.org/10.1177/003368820303400102

25. E.M. Markova, A.A. Pozdnyakova, T.E. Kolyadina, D.D. Dmitriyeva, V.V. Zotov, Integrative potential of educational resources in a modern metropolis, in SHS Web Conf, 98, 03013 (2021). https://doi.org/10.1051/shsconf/2021980301 